\title{
Biogenic isoprene in the Lower Fraser Valley, British Columbia
}

\author{
Kristina Curren and Terry Gillespie \\ Land Resource Science, University of Guelph, Guelph, Ontario, Canada \\ Douw Steyn \\ Geography, University of British Columbia, Vancouver, British Columbia, Canada
}

Thomas Dann and Daniel Wang

Environment Canada, River Road, Ottawa, Ontario, Canada

\begin{abstract}
Tropospheric ozone is formed by photochemical reactions between nitrogen oxides $\left(\mathrm{NO}_{x}\right)$ and volatile organic compounds. In some regions, biogenic isoprene may be a significant contributor to the production of tropospheric ozone. The contribution of biogenic isoprene is an important aspect of regional ozone chemistry as it represents an ozone precursor that cannot be eliminated through emissions controls. The purpose of this study was to evaluate the contribution of isoprene to the production of tropospheric ozone in the Lower Fraser Valley, British Columbia. Seasonal trends and diumal profiles were used to examine isoprene's relationship with temperature, to determine its source, and to investigate the chemical and physical factors that limit the ambient levels of isoprene present in the region. Total isoprene levels in the Lower Fraser Valley were low, and evidence suggested that a substantial fraction originated from anthropogenic rather than biogenic sources. Diumal isoprene profiles were generally flat, and the times of the highest concentrations did not coincide with peak $\mathrm{NO}_{\mathbf{x}}$ levels nor with the times of optimal ozoneproducing meteorological conditions. These results are consistent with those of previously reported studies and suggest that biogenic isoprene may not be as important to the tropospheric ozone chemistry in the Lower Fraser Valley as it is in some southern U.S. cities.
\end{abstract}

\section{Introduction}

Tropospheric ozone is a major component of urban smog that affects the health of people, crops, and natural vegetation. Tropospheric ozone is formed by photochemical reactions between nitrogen oxides $\left(\mathrm{NO}_{x}\right)$ and volatile organic compounds (VOCs). While most $\mathrm{NO}_{\mathrm{x}}$ originates from anthropogenic sources, VOCs may be emitted from both anthropogenic and biogenic sources. In recent years, it has become apparent that biogenic hydrocarbons, particularly isoprene $\left(\mathrm{C}_{5} \mathrm{H}_{8}\right)$, may be significant contributors to the production of tropospheric ozone in some areas. The contributions of biogenic hydrocarbons are an important aspect of regional ozone chemistry as they represent an ozone precursor that cannot be eliminated through emissions controls.

Previous studies that measured biogenic hydrocarbon emission rates from several species of vegetation showed that the Lower Fraser Valley contains few species of agricultural crops, natural plants, or trees that emit isoprene in appreciable amounts [Drewitt, 1996; Drewitt et al., 1998; Curren, 1998]. This suggests that ambient biogenic isoprene levels in the region should be generally low. It is possible, however, that there are isoprene-emitting species of plants present in the area that were not accounted for in the emissions studies and that ambient biogenic isoprene levels near these sources could be high enough to have a significant impact on the production of tropospheric ozone in the region.

This paper describes the methods and results from two analyses of ambient isoprene levels in the Lower Fraser Valley, British Columbia. The first study is an analysis of seasonal isoprene trends in the region.

Copyright 1998 by the American Geophysical Union.

Paper number 98JD01214.

0148-0227/98/98JD-01214\$09.00
The purpose of this study was to examine the ambient concentrations of isoprene throughout the year at various sites in the Lower Fraser Valley to determine if significant ambient concentrations of isoprene exist in the region; to examine isoprene's relationship with temperature; and to determine whether isoprene in the region originated from anthropogenic or biogenic sources. The second study served to examine the diumal variation in isoprene concentrations during summer ozone episode and non episode days in the Lower Fraser Valley and investigated the chemical and physical factors that produce the observed diumal isoprene profiles through the use of a simple box model. The results of these and previously published studies were used to evaluate the impact of biogenic isoprene in the Lower Fraser Valley on the regional production of tropospheric ozone.

\section{Background}

The Lower Fraser Valley is a roughly triangular valley in southwestem British Columbia that extends from the Strait of Georgia in the west to the Fraser Canyon in the east. The valley is bounded by the Coast Mountains to the north and the Cascade Mountains to the southeast and is inhabited by approximately 2 million people [Steyn et al., 1997]. The bulk of the anthropogenic ozone precursor emissions arises from mobile sources, primarily light-duty vehicles [Steyn et al., 1997]. The region's natural vegetation is largely made up of coniferous trees, including western red cedar (Thuja plicate), coastal Douglas fir (Psudotsuga menziesii ssp. menziesii), and coastal hemlock (Tsuga mertensiana) [Drewitt, 1996; Drewitt et al., 1998]. The valley floor has a range of urban and agricultural uses that results in considerable variation in local biogenic emissions [Singleton et al, 1996].

Although ambient isoprene concentrations in rural areas tend to be higher than those in urban areas due to the greater density of isoprene 
emitting plants in rural areas, significant ambient isoprene concentrations have been reported in urban areas. Midday summertime isoprene concentrations as high as $8 \mathrm{ppbv}$ have been recorded at in Atlanta, Georgia, although measurements of the order of 2.5 ppbv are more common [Cardelino and Chameides, 1995]. Ambient isoprene levels measured in Toronto, Ontario, showed that isoprene levels increased during the summer months in response to increasing emissions from biogenic sources. Summer isoprene concentrations at this site varied, but were consistently less than 1 ppbv [McLaren et al., 1996]. Isoprene concentrations measured at urban and suburban sites in the Lower Fraser Valley are generally less than $0.4 \mathrm{ppbv}$, with suburban sites showing slightly higher mixing ratios (0.2-0.35 ppbv) than urban sites $(<0.2 \mathrm{ppbv})$ [Canadian Council of Ministers of the of the Environment (CCME), 1997].

Isoprene is generally considered to originate from biogenic sources. Studies in Louisiana and Califomia have shown that the temperature dependence of ambient isoprene concentrations was consistent with laboratory-measured temperature dependence of biogenic emissions [National Research Council (NRC), 1991], that isoprene concentrations were negatively correlated with VOCs normally associated with anthropogenic mobile sources [Chameides et al., 1992], and that the diurnal profiles of isoprene were temporally out of phase with those of anthropogenic compounds [Chameides et al., 1992].

At some sites, however, isoprene may have an anthropogenic source. Detectable levels of isoprene were measured at York University during the winter months when biogenic sources were dormant under snow cover. An analysis of this data showed a significant correlation between isoprene and 1,3 butadiene, a well known combustion product, indicating that the isoprene levels observed in the winter months originated from anthropogenic mobile sources [McLaren et al.,1996]. Chemical mass balance modeling of this data indicated that the observed winter isoprene concentrations could be accounted for by vehicle exhaust containing isoprene at a level of $0.0018 \%$ of nonmethane hydrocarbon mass in the exhaust [McLaren et al., 1996].

Similarly, an anthropogenic source of isoprene has been suggested for the Lower Fraser Valley. A correlation between ambient isoprene concentrations at several of the sampling sites in the Lower Fraser Valley and the corresponding isoprene emission rates predicted by PC-BEIS [Pierce and Waldruff, 1991] showed a general trend of increasing concentrations with increasing ambient emissions [Singleton et al., 1996], but isoprene concentrations at a site in the urban center of Vancouver appeared to be anomalously high. Possible explanations proposed to explain the reading from this site included confounding effects of very local biogenic sources or that some of the measured isoprene originated from vehicle exhaust [McLaren et al., 1996; Singleton et al., 1996]. PC-BEIS does not include anthropogenic isoprene in the vehicle exhaust profile [Singleton et al., 1996].

In addition to isoprene's absolute concentration, the diurnal patterns of isoprene emissions must be considered when evaluating its contribution to the production of tropospheric ozone. The diurnal variations in isoprene and other ozone precursor concentrations are important considerations because all precursors may not be present in appreciable concentrations in the ambient atmosphere at the same time. Data collected at several urban sites in the southern United States showed that anthropogenic hydrocarbons and $\mathrm{NO}_{\mathrm{x}}$ both peaked during the early morning and evening rush hours [Chameides et al., 1992]. Similarly, total nonmethane hydrocarbons and $\mathrm{NO}_{\mathrm{x}}$ mixing ratios measured in the Lower Fraser Valley showed minima in the afternoon due to enhanced mixing and peaks during the evening and morning rush hours when emissions were high and the mixed layer was shallow [CCME, 1997].
Isoprene emitted from biogenic sources, on the other hand, may show a different diumal profile from anthropogenic compounds. Isoprene mixing ratios measured at rural forest sites, where areal emission rates are high, are generally low in the early morning, rise sharply at sunrise, and continue to increase throughout the day in response to increasing temperatures [Trainer et al., 1987; Fehsenfelt et al., 1992]. Isoprene profiles measured at urban sites in the Atlanta, Georgia, region showed a different shape from those at forest sites, with isoprene mixing ratios at all but one of these sites roughly constant throughout most of the day [Cardelino and Chameides, 1995]. Three of the sites showed slightly elevated levels of isoprene in the morning, possibly due to active biogenic sources combined with the relatively shallow mixing layer, while two of the sites showed dramatic increases in isoprene levels late in the afternoon, probably as the result of the collapse of the mixing layer and decreasing concentrations of compounds that act as isoprene sinks. The profile measured at the Fort McPherson site was similar to profiles over forests at rural sites, with isoprene levels higher than 5 ppbv for most of the day. No explanation was given for the consistently high levels of isoprene measured at this site [Cardelino and Chameides, 1995].

\section{Methods}

\subsection{Data Collection}

The data used in this analysis were obtained from the national field sampling program database maintained by the Pollution Measurement Division of the Environment Protection Service, Environment Canada [Dann et al., 1994; CCME, 1997]. Systematic year round measurements at several urban sites and one suburban site in the Lower Fraser Valley began in 1989, with several nonurban sites added to the program in later years (Table 1 ). Sites were classified as urban, urban street (close to street level in the urban core), or suburban (in an urban area but outside the urban core), and note was made of sites that were potentially impacted by industrial emissions. No data were available from rural sites in the region.

Field samples were collected by provincial or municipal environment departments participating in the National Air Pollution Surveillance program. Samples were normally collected over a 24 hour period once every 6 days, with more intensive sampling programs conducted at Rocky Point Park during the summers of 1992 and 1993. In addition to the 24 hour samples, eight sequential 3 hour samples were collected at various sites in the Lower Fraser Valley on selected days in 1992 and 1993 [CCME,1997]. Whole air samples were collected in $6 \mathrm{~L}$ electropolished stainless steel canisters and were analyzed in Environment Canada's Ottawa laboratory. Studies have shown that VOC mixtures can be stored for up to 30 days in these canisters with little change in composition [Oliver et al., 1986]. The whole air samples were analyzed using a cryogenic preconcentration technique and a gas chromatograph coupled with a flame ionization detector or a mass selective detector. The analytical system was based

Table 1. Ambient NMHC Measurement Sites in the Lower Fraser Valley

\begin{tabular}{|c|c|c|c|}
\hline Site & $\begin{array}{l}\text { Site } \\
\text { Classification }\end{array}$ & $\begin{array}{l}\text { Industrial } \\
\text { Source }\end{array}$ & Start Date \\
\hline Kensington Park & urban & refinery & Jan. 4, 1989 \\
\hline Rocky Point Park & urban & refinery & Jan. 4, 1989 \\
\hline Robson Street & urban street & & Jan. 28,1989 \\
\hline Surrey East & suburban & & Jan. 10,1989 \\
\hline Richmond South & urban & & Jan. 22, 1989 \\
\hline Mahon Park & urban & & May 23,1990 \\
\hline Shellmount Street & suburban & $\begin{array}{l}\text { pipeline } \\
\text { transfer }\end{array}$ & March 18,1990 \\
\hline Langley & suburban & & July 12,1993 \\
\hline
\end{tabular}


on the methods described by Winberry et al. [1988] and is further described by Dann et al. [1994] and Bottenheim et al. [1997]. Typical detection limits for this method were $0.02-0.04 \mathrm{ppbv}$, species values that were below detection level were set to zero [CCME, 1997]. The reported precision of the method for analytes with concentrations greater than $0.25 \mathrm{ppbv}$ was in the range of 10-15\% [Dann et al., 1994].

\subsection{Seasonal Data Analysis}

Seasonal trends in isoprene mixing ratios were examined by combining all available data for each station. The relationships between isoprene and the daily mean temperature measured at the Abbotsford airport in summer and winter were examined for each station, and regression equations were calculated where appropriate. For the purposes of this analysis, "winter" was defined as the period between November and March and "summer" as the period between May and September. The transitional months of April and October were excluded from the temperature analysis [McLaren et al., 1996]. A large number of data points were available for Rocky Point Park $(n=306)$, with considerably fewer data available for other stations.

Regressions between ambient concentrations of isoprene and trans-2-pentene and cis-2-butene, VOCs normally associated with anthropogenic mobile sources, were performed to test the hypothesis that isoprene in the Lower Fraser Valley originates at least partly from anthropogenic sources. The data were logarithmically transformed for the regressions to ensure constant variance throughout the range of measured concentrations. In order to perform the transformations, zero readings were replaced with concentrations equal to half the detection limit (0.02 ppbv). Separate regressions were performed for the winter and summer months. Again, considerable data were available for Rocky Point Park ( $\mathrm{n}=359$ ), while far fewer data were available for the other sites.

\subsection{Diurnal Data Analysis}

Diurnal isoprene profiles at two sites, Rocky Point Park and Langley, were constructed for non episode days and for selected days during the mild ozone episode of 1993. Average non episode day profiles were created by combining data for days with similar daily maximum temperatures, while profiles for the episode days represent a single day's data.

\subsection{Bor Model}

Diumal isoprene profiles in the Lower Fraser Valley were reproduced using a simple box model. For the purposes of this analysis, isoprene advection, deposition, and entrainment from above the mixing layer were assumed to be zero. Under these assumptions, the concentration of isoprene within the $1 \mathrm{~km} \mathrm{x} 1 \mathrm{~km}$ box was dependent upon the initial concentration of isoprene at the start of the day, the areal anthropogenic and biogenic isoprene source strengths, the depth of the mixing layer, and the strength of atmospheric isoprene sinks. Each of these factors will be discussed below in turn.

3.4.1. Initial concentration of isoprene. The diumal isoprene profiles at Rocky Point Park and Langley indicated that low concentrations of isoprene existed in the ambient atmosphere during pre dawn hours. Isoprene concentrations measured at 0300 hours (representing the average mixing ratio from $0300-0600$ hours) were used as the initial concentration within the box at the start of the day.

3.4.2. Areal isoprene source strength. Biogenic and anthropogenic sources of isoprene were included in the model. Biogenic isoprene emission rates are primarily dependent upon temperature and illumination. The length of day and the temperature profile for the day were calculated using the model of Parton and Logan [1981], which assumes a sinusoidal temperature trend from sunrise to sunset and an exponential decay from sunset to the following sunrise. The radiation profile was assumed to be sinusoidal, increasing from zero at sunrise to a maximum of $1600 \mu \mathrm{mol} \mathrm{m}^{-2} \mathrm{~s}^{-1}$ at noon and returning to zero at sunset [Oke, 1978]. Cloud cover was assumed to be zero for the non episode days and for 2 of the 3 episode days (August 2, 1993 (Langley), and August 5, 1993 (Rocky Point Park)). In accordance with recorded meteorological data during Pacific '93, observations of cloud cover for August 4, 1993 (Langley) were used to reduce the illumination at that site. Temperature- and illumination-dependent isoprene emission rates were calculated using the following algorithms from Guenther et al. [1991]:

$$
\mathbf{E}=\mathbf{S} \times \mathbf{T}^{\prime} \times \mathbf{L}^{\prime}
$$

where $E$ is the isoprene emission rate $\left(\mu \mathrm{g} \mathrm{m}^{-2} \mathrm{~h}^{-1}\right) ; \mathrm{S}$ is the mean isoprene emission rate at $301 \mathrm{~K}\left(\mu \mathrm{g} \mathrm{m}^{-2} \mathrm{~h}^{-1}\right)$; $\mathrm{T}^{\prime}$ is the correction factor for temperature; and L' is the correction factor for illumination.

$$
T^{\prime}=\frac{\exp \left[T_{1}\left(T_{L}-T_{S}\right) / R T_{L} T_{S}\right]}{1+\exp \left[T_{2}\left(T_{L}-T_{3}\right) / R T_{L} T_{S}\right]}
$$

where $T_{L}$ is the leaf temperature $\approx$ air temperature; $T$ is the nonnalizing temperature $(301 \mathrm{~K}) ; \mathrm{R}=8.314 \mathrm{~J} \mathrm{~K}^{-1} \mathrm{~mol}^{-1} ; \mathrm{T}_{1}=95,100$ $\mathrm{J} \mathrm{mol}^{-1} ; \mathrm{T}_{2}=231,000 \mathrm{~J} \mathrm{~mol}^{-1}$; and $\mathrm{T}_{3}=311.83 \mathrm{~K}$.

$$
L^{\prime}=\frac{x-\left(x^{2}-4 \times f \times I \times L_{1}\right)}{2 L_{1}}
$$

where $x=f \times I+L_{1}+L_{2} ; f$ is the fraction of light absorbed by chloroplasts $(=0.385)$; $\mathrm{I}$ is the irradiance $\left(\mu \mathrm{mol} \mathrm{m}^{-2} \mathrm{~s}^{-1}\right) ; \mathrm{L}_{1}=105.6$ $\mu \mathrm{mol} \mathrm{m} \mathrm{m}^{-2} \mathrm{~s}^{-1}$; and $\mathrm{L}_{2}=6.12 \mu \mathrm{mol} \mathrm{m} \mathrm{m}^{-2} \mathrm{~s}^{-1}$. Correction factors for humidity and $\mathrm{CO}_{2}$ mixing ratios were neglected as these corrections are very small. The mean areal isoprene emission rate $(S)$ for the Lower Fraser Valley at $301 \mathrm{~K}$ has been estimated at $226 \mu \mathrm{g} \mathrm{m}^{-2} \mathrm{~h}^{-1}$ [Drewitt, 1996]. Visual inspection of a satellite image of the region revealed that the density of foliage in the vicinity of the Langley site was greater than that surrounding Rocky Point Park. Accordingly, the mean areal biogenic isoprene emission rate for Langley was set at $226 \mathrm{~g} \mathrm{~m} \mathrm{~m}^{-2} \mathrm{~h}^{-1}$ for this analysis, while the rate for Rocky Point Park was set at $169.5 \mu \mathrm{g} \mathrm{m}^{-2} \mathrm{~h}^{-1}$.

Hourly estimates of anthropogenic isoprene emissions were made by assuming that anthropogenic isoprene is emitted only by mobile sources (automobiles). Based on the results of the seasonal isoprene analysis, the total amount of anthropogenic isoprene emitted in the region over the course of a day was assumed to be $25 \%$ of the value of the total biogenic isoprene emitted in the region on a day of moderate temperature. Thus the gross amount of anthropogenic isoprene emitted in the Lower Fraser Valley was assigned a value of $9 \times 10^{10} \mu \mathrm{g} \mathrm{d}^{-1}$, or $225 \mu \mathrm{g} \mathrm{m}^{-2} \mathrm{~d}^{-1}$. This total amount was partitioned into hourly emissions using the relative allocation factors from the Pacific '93 VOC emission inventory [Levelton, 1996; Jiang et al. 1996]. Relative allocation factors were available for July 31 to August 6,1993 . For the non episode days, averaged relative allocation factors were used to calculate hourly anthropogenic emission rates, while the factors from specific days were used for the episode days.

3.4.3 Depth of mixing layer. The depth of the modelled mixing layer varied with time of day. The nighttime depth of the mixing layer was $200 \mathrm{~m}$. The mixing layer began to grow shortly after sunrise and followed a sinusoidal curve until its maximum depth was reached at 1500 hours. The mixing layer collapsed 1 hour before sunset to a depth of $200 \mathrm{~m}$. In addition to temporal variation, the depth of the mixing layer over a coastal region also varies spatially. Air flowing from offshore to onshore is modified by changes in temperature contrasts, which produce a thermal or convective internal boundary layer. The growth of the convective internal boundary layer can be represented by the following equation [Venkatram, 1977; Hsu, 1986]: 


$$
h=\frac{\left(2 C_{d}\left(\theta_{10 a d}-\theta_{\text {mand }}\right) X\right)^{05}}{(\gamma(1-2 F))^{0.5}}
$$

where $h$ is the depth of the mixing layer $(m) ; C_{d}$ is the drag coefficient; $\boldsymbol{\theta}_{\text {mad }}$ is the potential air temperature over land $\left({ }^{\circ} \mathrm{C}\right) ; \boldsymbol{\theta}_{20}$ is the potential air temperature over sea $\left({ }^{\circ} \mathrm{C}\right) ; \mathrm{X}$ is the distance downwind from the shoreline $(\mathrm{m}) ; \gamma$ is the lapse rate above the boundary layer $\left({ }^{\circ} \mathrm{C} / \mathrm{m}\right)$; and $F$ is the entrainment coefficient.

Equation (4) was used to calculate the maximum depth of the mixing layer for the modeled nonepisode days. The distances of Rocky Point Park and Langley downwind from the shoreline were estimated using the simplified Lower Fraser Valley shoreline depicted by Steyn and Oke [1982, Figure 5], and assuming a west-southwest airflow. The values of the parameters entered into equation (4) were as follows $C_{d}=0.012, \theta_{m a}=16-17^{\circ} \mathrm{C}, X=29.4 \mathrm{~km}$ (Rocky Point Park) and 32 $\mathrm{km}$ (Langley), $\gamma=0.065^{\circ} \mathrm{C} / \mathrm{m}$, and $\mathrm{F}=0.2$. The resulting calculated maximum mixing layer depths varied between 650 and $900 \mathrm{~m}$.

The maximum mixing layer depths entered into the model for the ozone episode days of August 2 (Langley), August 4 (Langley), and August 5 (Rocky Point Park) were taken from the measured depths reported by Hayden et al. [1997]. In general, the measured depth of the mixing layer from August 1-5, 1993, ranged from 500-800 $\mathrm{m}$ in the center of the valley.

3.4.4. Isoprene sinks. The oxidation of isoprene in the ambient atmosphere is initiated by reaction with $\mathrm{OH}$ and $\mathrm{NO}_{3}$ radicals and with $\mathrm{O}_{3}$. For the purposes of this model, $\mathrm{OH}$ radicals were considered as the primary sink for isoprene during the day, and $\mathrm{NO}_{3}$ radicals were considered as the primary sink for isoprene during the night. The reaction between isoprene and ozone is much slower than that between isoprene and $\mathrm{OH}$ or $\mathrm{NO}_{3}$, and $\mathrm{O}_{3}$ levels are generally low in the Lower Fraser Valley during nonepisode days and very low at night; thus the reaction between isoprene and $\mathrm{O}_{3}$ was neglected in this analysis.

The $\mathrm{OH}$ profile used in this analysis was sinusoidal, with concentrations increasing from zero after sunrise, reaching a peak concentration at noon, and returning to zero shortly before sunset. The shape of the $\mathrm{OH}$ profile was chosen to correspond with the radiation profile as $\mathrm{OH}$ is formed by the photolysis of $\mathrm{O}_{3}$. $\mathrm{OH}$ concentrations are difficult to measure, and no data were available for this analysis. For nonepisode days, peak concentrations of $\mathrm{OH}$ radicals were taken to be $1 \times 10^{6}$ radicals $\mathrm{cm}^{-3}$ (N. Bunce, University of Guelph, personal communication, 1998).

Since $\mathrm{O}_{3}$ is required for the production of $\mathrm{OH}$ radicals and $\mathrm{NO}_{2}$ is a sink for $\mathrm{OH}, \mathrm{OH}$ concentrations may be depressed under conditions of moderate $\mathrm{O}_{3}$ and elevated $\mathrm{NO}_{x}$. The 1993 ozone episode was mild, with peak $\mathrm{O}_{3}$ concentrations at Rocky Point Park and Langley ranging from 54-72 ppbv and peak daytime $\mathrm{NO}_{\mathrm{x}}$ levels ranging from 30-67 ppbv. For these days, the peak $\mathrm{OH}$ concentration was taken to be $1 \times 10^{5}$ radicals $\mathrm{cm}^{-3}$ (N. Bunce, University of Guelph, personal communications, 1998).

Peak concentrations of $\mathrm{NO}_{3}$ radicals and the shape of night time $\mathrm{NO}_{3}$ profiles can vary substantially from night to night [Platt et al., 1981; Finlayson-Pitts and Pitts, 1986]. For this simulation, $\mathrm{NO}_{3}$ was increased linearly from zero at sunset and reached its peak concentration of $10 \mathrm{ppt} 2$ hours after the onset of darkness. This profile was chosen as it roughly matched the shape of a measured profile at Deuselbach, West Germany, where $\mathrm{NO}_{3}$ levels rose at 1900 hours and reached a peak at 2100 hours [Platt et al., 1981]. In addition, $\mathrm{NO}_{3}$ is likely to be formed from $\mathrm{NO}_{2}$ emitted from the evening rush hour. Peak concentrations of $\mathrm{NO}_{3}$ were maintained until midnight, whereupon they decreased sinusoidally, reaching a concentration of 0 ppt at dawn.

\section{Results and Discussion}

\subsection{Seasonal Analysis}

Mean daily isoprene concentrations and temperatures throughout the year at Rocky Point Park are shown in Figure 1. In general, isoprene mixing ratios were low, with a mean of $0.16 \mathrm{ppbv}(n=162)$

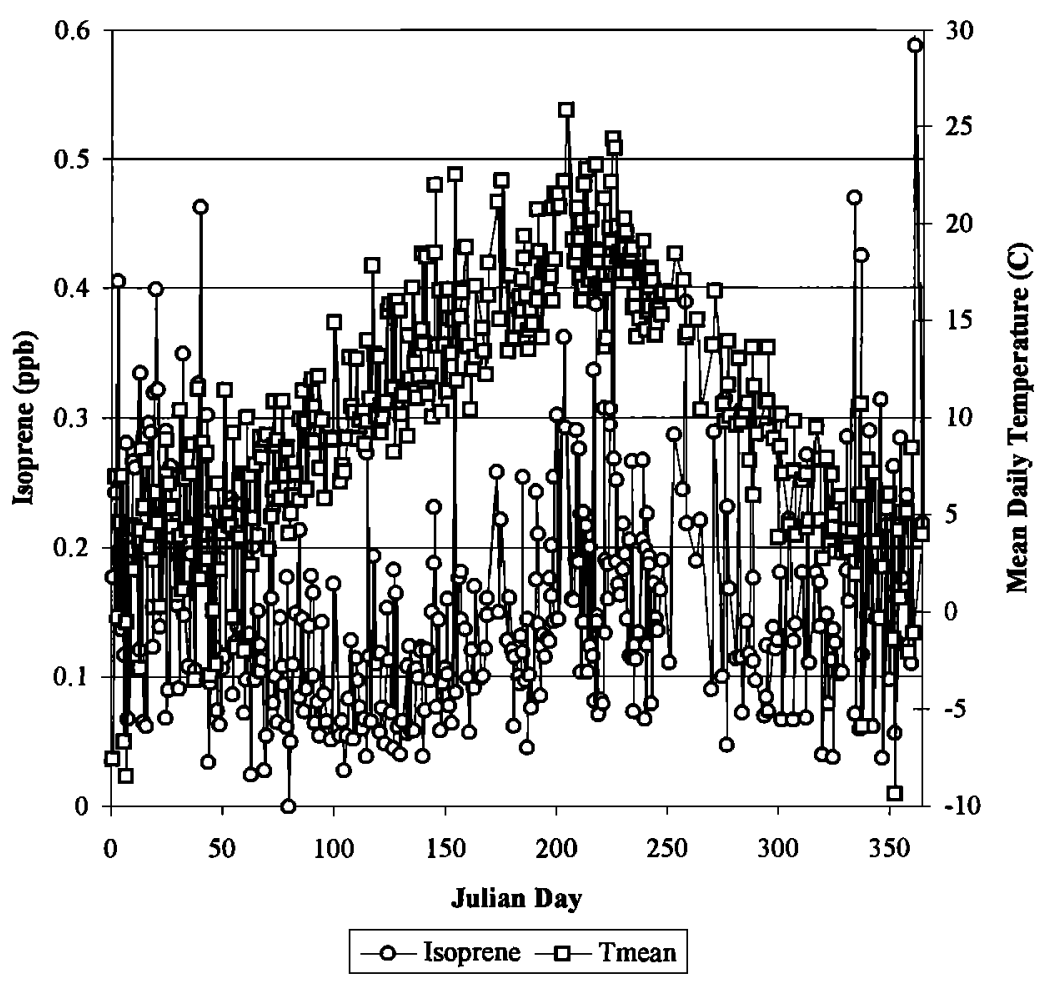

Figure 1. Seasonal isoprene and temperature trends at Rocky Point Park, 1989-1995 
Table 2. Mean and Maximum Isoprene Mixing Ratios

\begin{tabular}{lllll}
\hline & \multicolumn{2}{c}{ Summer } & & \multicolumn{2}{c}{ Winter } \\
\cline { 2 - 3 } \cline { 5 - 6 } $\begin{array}{llll}\text { Mean, } \\
\text { Spbv }\end{array}$ & $\begin{array}{l}\text { Maximum, } \\
\text { ppbv }\end{array}$ & $\begin{array}{l}\text { Mean, } \\
\text { ppbv }\end{array}$ & $\begin{array}{l}\text { Maximum, } \\
\text { ppbv }\end{array}$ \\
\hline $\begin{array}{l}\text { Rocky Point Park } \\
\text { (Urban) }\end{array}$ & $\begin{array}{l}0.16 \\
(\mathrm{n}=162)\end{array}$ & 0.44 & $\begin{array}{l}0.17 \\
(\mathrm{n}=144)\end{array}$ & 0.58 \\
$\begin{array}{l}\text { Kensington } \\
\text { (Urban) }\end{array}$ & $\begin{array}{l}0.15 \\
(\mathrm{n}=28)\end{array}$ & 0.33 & $\begin{array}{l}0.14 \\
(\mathrm{n}=20)\end{array}$ & 0.24 \\
$\begin{array}{l}\text { Mahon Park } \\
\text { (Urban) }\end{array}$ & $\begin{array}{l}0.16 \\
(\mathrm{n}=15)\end{array}$ & 0.43 & $\begin{array}{l}0.09 \\
(\mathrm{n}=15)\end{array}$ & 0.22 \\
$\begin{array}{l}\text { Richmond South } \\
\text { (Urban) }\end{array}$ & $\begin{array}{l}0.15 \\
(\mathrm{n}=22)\end{array}$ & 0.46 & $\begin{array}{l}0.21 \\
(\mathrm{n}=14)\end{array}$ & 0.47 \\
$\begin{array}{l}\text { Robson Street } \\
\text { (Urban - Street) }\end{array}$ & $\begin{array}{l}0.10 \\
(\mathrm{n}=23)\end{array}$ & 0.19 & $\begin{array}{l}0.14 \\
(\mathrm{n}=16)\end{array}$ & 0.77 \\
$\begin{array}{l}\text { Shellmount Street } \\
\text { (Suburban) }\end{array}$ & $\begin{array}{l}0.15 \\
(\mathrm{n}=41)\end{array}$ & 0.49 & $\begin{array}{l}0.09 \\
(\mathrm{n}=52)\end{array}$ & 0.32 \\
$\begin{array}{l}\text { Surrey East } \\
\text { (Suburban) }\end{array}$ & $\begin{array}{l}0.10 \\
(\mathrm{n}=19)\end{array}$ & 0.29 & $\begin{array}{l}0.04 \\
(\mathrm{n}=22)\end{array}$ & 0.18 \\
$\begin{array}{l}\text { Langley } \\
\text { (Suburban) }\end{array}$ & $\begin{array}{l}0.22 \\
(\mathrm{n}=10)\end{array}$ & 0.64 & $\begin{array}{l}0.02 \\
(\mathrm{n}=8)\end{array}$ & 0.05 \\
\hline
\end{tabular}

in the summer and $0.17 \mathrm{ppbv}(\mathrm{n}=144)$ in the winter. Peak summer isoprene concentrations of $0.36 \mathrm{ppbv}$ or higher were recorded on five occasions, generally on warm days; the highest summer concentration of isoprene recorded was $0.44 \mathrm{ppbv}$ (August 12, 1992). Winter concentrations of $0.36 \mathrm{ppbv}$ or more were recorded on seven occasions; the highest winter concentration recorded was $0.58 \mathrm{ppbv}$ (December 27, 1993). These results contrast with those at York University, where summer concentrations of isoprene were higher than winter concentrations [McLaren et al., 1996].

Table 2 shows the mean and maximum summer and winter isoprene mixing ratios for all stations. Although the number of data points at stations other than Rocky Point Park was limited, some trends can be discerned. Mean summer isoprene mixing ratios were similar at most sites, with slightly higher averages recorded at Langley, the most easterly and least urban site. Mean winter isoprene mixing ratios were similar to or slightly higher than summer values for the urban sites, but lower than summer values at suburban sites. Maximum summer isoprene concentrations were less than $0.5 \mathrm{ppbv}$ at all stations, except for Langley where the maximum isoprene measured was 0.64 ppbv. Maximum winter isoprene concentrations were also less than $0.5 \mathrm{ppbv}$ for all stations, except for Rocky Point Park and Robson Street. The reading of $0.77 \mathrm{ppbv}$ at Robson Street on January 28, 1989, was the highest recorded in the region and supports the hypothesis that anthropogenic sources and a shallow mixing depth can occasionally result in very high ambient isoprene concentrations.

The concentrations of isoprene observed at Rocky Point Park and other sites during the winter are probably also enhanced by the shallow mixing layer, but these results indicate active local sources of isoprene during the winter months, particularly in urban areas. The source is unlikely to be a biogenic one, as most plants in the region are dormant during this time. Although some plant species in the Vancouver area remain green throughout the mild winter, temperatures are too low for substantial biogenic emissions.

Figures 2 and 3 show the relationship between mean daily isoprene mixing ratios and temperatures during the summer and winter months at Rocky Point Park. Figure 2 shows a clear relationship between isoprene and temperatures greater than $15^{\circ} \mathrm{C}$ in the summer, while Figure 3 shows a complete lack of correlation between the two in the winter. Biogenic emissions increase with increasing temperature; thus these results suggest that the isoprene measured at Rocky Point Park in the winter months does not originate from a biogenic source. Similar relationships between ambient isoprene concentrations and temperature during summer and winter were observed at the other sites (data not shown).

The relationship between isoprene and temperature in the summer falls into two groupings. Isoprene mixing ratios at daily mean

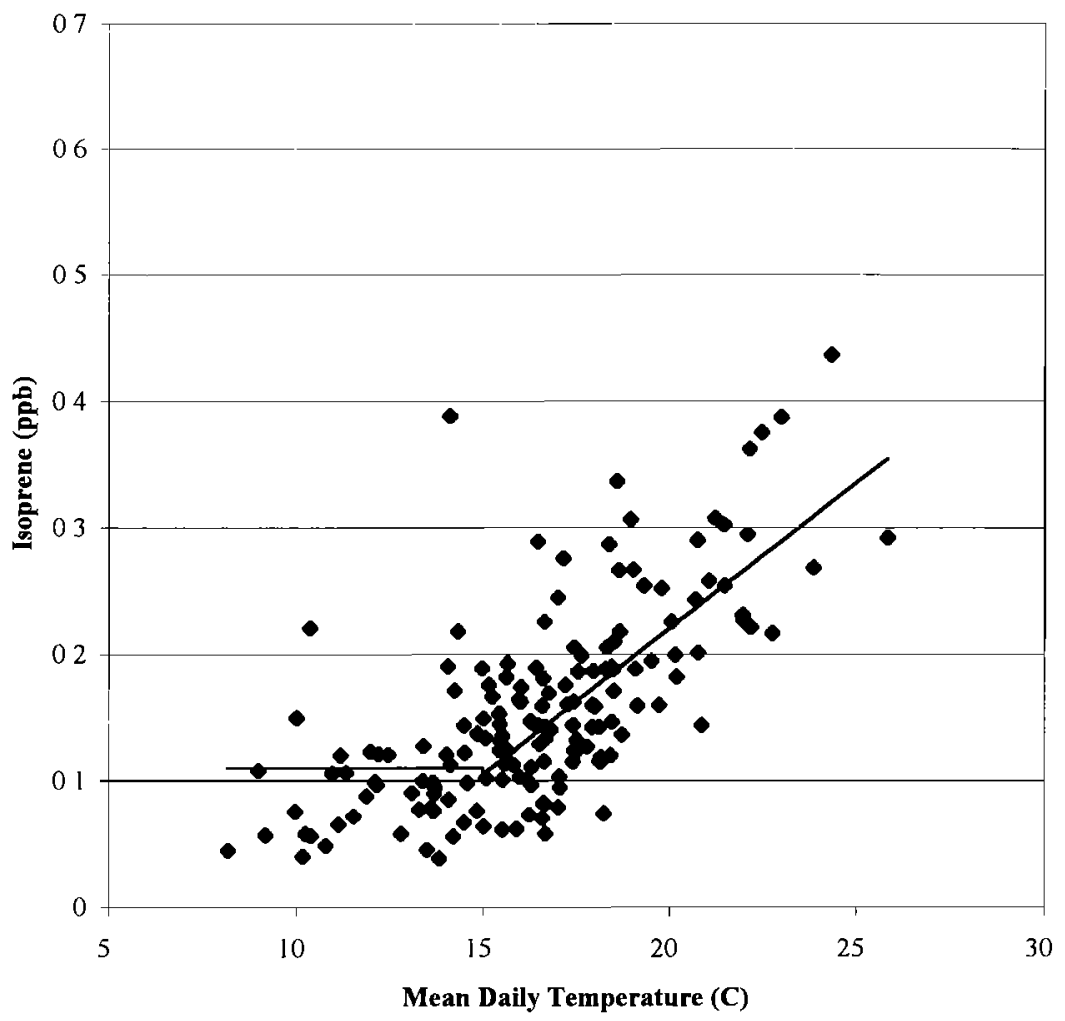

Figure 2. The relationship between isoprene and temperature at Rocky Point Park during summer. 


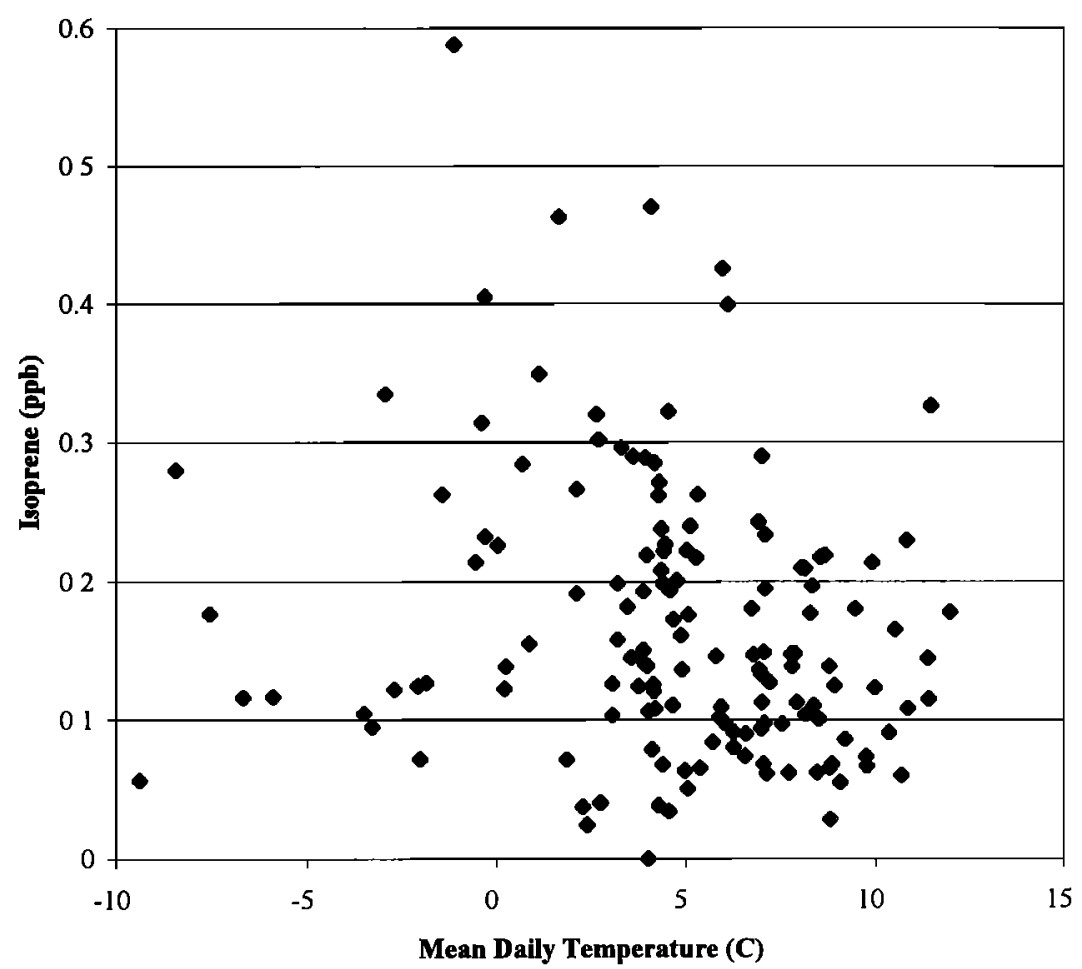

Figure 3. The Relationship Between Isoprene and Temperature at Rocky Point Park during winter.

temperatures less than approximately $15^{\circ} \mathrm{C}$ are variable (likely as the result of varying meteorological conditions on specific days), but show no correlation with temperature. Biogenic emissions at daily mean temperatures below $15^{\circ} \mathrm{C}$ (corresponding to a daily maximum temperature of about $20^{\circ} \mathrm{C}$ ) should be very small. The isoprene measured on these days probably originates from the same anthropogenic source as the isoprene measured during the winter months, while the isoprene measured on warmer days is a mixture of isoprene from both biogenic and anthropogenic sources.

Table 3 shows the average summer isoprene mixing ratios on days with mean temperatures less than $15^{\circ} \mathrm{C}$ for all Lower Fraser Valley sites. Although data are limited at sites other than Rocky Point Park, these values give rough indications of the background anthropogenic level of isoprene concentrations during the summer at each of these sites.

Isoprene concentrations at Rocky Point Park on warm summer days $\left(\mathrm{T}_{\text {meen }}>20^{\circ} \mathrm{C}\right.$, corresponding to $\mathrm{T}_{\max }>27^{\circ} \mathrm{C}$ ) ranged from $0.14-0.44 \mathrm{ppbv}$, while the background level of isoprene on cool days $\left(\mathrm{T}_{\text {meen }}<15^{\circ} \mathrm{C}\right)$ was $0.11 \mathrm{ppbv}$. Background anthropogenic isoprene may therefore account for $\mathbf{2 5 - 7 8 \%}$ of the total observed isoprene load at Rocky Point Park.

Although Guenther et al. [1991] calculated an exponential equation for biogenic isoprene emission rates with increasing

Table 3. Mean Summer Isoprene Mixing Ratios for Days with Mean Temperatures $<15^{\circ} \mathrm{C}$

\begin{tabular}{lcc}
\hline Site & Mean Isoprene Mixing Ratio ppbv & n \\
\hline Rocky Point Park & 0.11 & 54 \\
Kensington Park & 0.08 & 11 \\
Mahon Park & 0.14 & 7 \\
Richmond South & 0.11 & 5 \\
Robson Street & 0.10 & 10 \\
Shellmount Strect & 0.08 & 22 \\
Surrey East & 0.04 & 6 \\
Langley & 0.10 & 2 \\
\hline
\end{tabular}

temperature, the relationship between ambient isoprene.concentrations and temperature is not necessarily exponential due to the effects of changing meteorological conditions and the changing strengths of isoprene sinks. There were sufficient summer data for Rocky Point Park to perform a regression between daily mean isoprene mixing ratio and temperature. The increase in isoprene concentration with temperature for daily mean temperatures greater than $15^{\circ} \mathrm{C}$ was approximately linear. Thus the daily mean isoprene mixing ratio at Rocky Point Park can be characterized by equation (5):

$$
\begin{aligned}
\text { Isoprene (ppbv) } & =0.11, \mathrm{~T}_{\text {mean }}<15^{\circ} \mathrm{C}, \\
& =0.023 \times \mathrm{T}_{\text {mean }}-0.24, \mathrm{~T}_{\text {mean }}>15^{\circ} \mathrm{C}, \mathrm{r}^{2}=0.50
\end{aligned}
$$

Correlation coefficients for regressions between isoprene, trans-2-pentene, and cis-2-butene for all sites are shown in Table 4. Isoprene was positively correlated with both cis-2-butene and trans-2-pentene at all sites in both summer and winter. Positive correlations were also observed between the two anthropogenic compounds. These results are in contrast to those of Chameides et al. [1992] for southem U.S. cities and indicate that an anthropogenic source of isoprene exists in the Lower Fraser Valley during both summer and winter.

Seasonal differences in correlations between isoprene and the anthropogenic hydrocarbons were variable. At Rocky Point Park, the station with the most data available, the correlations were higher in the winter than in the summer. This result can be interpreted to indicate that anthropogenic isoprene accounted for a higher fraction of the total isoprene load in the winter than in summer. This trend was not consistently observed at other sites, but this may be the result of limited data at these sites.

\subsection{Diurnal Analysis}

4.2.1. Ambient diurnal isoprene measurements. Average diumal isoprene profiles for Rocky Point Park and Langley are shown in Figure 4. Data for nonepisode days with similar maximum 
Table 4. Correlation Coefficients for Isoprene, cis-2-Butene, and trans-2-Pentene

\begin{tabular}{|c|c|c|c|c|c|}
\hline \multirow[t]{2}{*}{ Station } & \multirow[t]{2}{*}{ Compound } & \multicolumn{2}{|c|}{ Summer } & \multicolumn{2}{|c|}{ Winter } \\
\hline & & $\mathbf{r}$ & $\mathbf{n}$ & $\mathbf{r}$ & $\mathbf{n}$ \\
\hline \multirow{3}{*}{$\begin{array}{l}\text { Rocky Point } \\
\text { Park } \\
\text { (Urban) }\end{array}$} & cis-2-butene/isoprene & 0.64 & 192 & 0.73 & 157 \\
\hline & trans-2-pentene/lioprene & 0.68 & 192 & 0.81 & 157 \\
\hline & $\begin{array}{l}\text { cis-2-butene/trans-2- } \\
\text { pentene }\end{array}$ & 0.82 & 192 & 0.75 & 157 \\
\hline \multirow{3}{*}{$\begin{array}{l}\text { Kensington } \\
\text { (Urban) }\end{array}$} & cis-2-butene/isoprene & 0.76 & 29 & 0.63 & 22 \\
\hline & trans-2-pentene/isoprene & 0.62 & 29 & 0.8 & 22 \\
\hline & $\begin{array}{l}\text { cis-2-butene/trans-2- } \\
\text { pentene }\end{array}$ & 0.84 & 29 & 0.82 & 22 \\
\hline \multirow{3}{*}{$\begin{array}{l}\text { Richmond } \\
\text { South } \\
\text { (Urban) }\end{array}$} & cis-2-butene/isoprene & 0.82 & 24 & 0.72 & 16 \\
\hline & trans-2-pentene/isoprene & 0.75 & 24 & 0.58 & 16 \\
\hline & $\begin{array}{l}\text { cis-2-butene/trans-2- } \\
\text { pentene }\end{array}$ & 0.73 & 24 & 0.72 & 16 \\
\hline \multirow{3}{*}{$\begin{array}{l}\text { Robson } \\
\text { Street } \\
\text { (Urban) }\end{array}$} & cis-2-butene/isoprene & 0.79 & 24 & 0.39 & 17 \\
\hline & trans-2-pentene/isoprene & 0.86 & 24 & 0.59 & 17 \\
\hline & $\begin{array}{l}\text { cis-2-butene/trans-2- } \\
\text { pentene }\end{array}$ & 0.89 & 24 & 0.24 & 17 \\
\hline \multirow{3}{*}{$\begin{array}{l}\text { Surrey East } \\
\text { (Suburban) }\end{array}$} & cis-2-butene/isoprene & 0.17 & 21 & 0.49 & 23 \\
\hline & trans-2-pentene/isoprene & 0.57 & 21 & 0.82 & 23 \\
\hline & $\begin{array}{l}\text { cis-2-butene/trans-2- } \\
\text { pentene }\end{array}$ & 0.37 & 21 & 0.37 & 23 \\
\hline \multirow{3}{*}{$\begin{array}{l}\text { Langley } \\
\text { (Suburban) }\end{array}$} & cis-2-butene/isoprene & 0.73 & 12 & 0.62 & 10 \\
\hline & trans-2-pentene/isoprene & 0.81 & 12 & 0.68 & 10 \\
\hline & $\begin{array}{l}\text { cis-2-butene/trans-2- } \\
\text { pentene }\end{array}$ & 0.90 & 12 & 0.69 & 10 \\
\hline
\end{tabular}

temperatures at each site were grouped, and the average profiles were graphed. The times indicated on the graphs mark the first hour of the 3 hour sample. In general, both Rocky Point Park and Langley showed flat profiles with low concentrations of isoprene on nonepisode days with maximum temperatures less than $25^{\circ} \mathrm{C}$ (Figure 4a). Isoprene profiles at other sites (data not shown) were similar to those depicted in Figure 4a. Daytime concentrations of isoprene on nonepisode days with $\mathrm{T}_{\max }<25^{\circ} \mathrm{C}$ were less than $0.3 \mathrm{ppbv}$ at both sites. Profiles at Langley on warmer days $\left(\mathrm{T}_{\max }>25^{\circ} \mathrm{C}\right)$ displayed slightly higher concentrations throughout the day (0.2-0.5 ppbv). Increases in isoprene concentrations were observed late in the afternoon on some days, likely as a result of the collapsing boundary layer. Rocky Point Park tended to have higher isoprene concentrations than Langley on cool days $\left(\mathrm{T}_{\max }<20^{\circ} \mathrm{C}\right)$, probably due to higher anthropogenic emissions in the urban area. Conversely, Langley tended to have higher isoprene concentrations on warm days $\left(\mathrm{T}_{\max }>20^{\circ} \mathrm{C}\right)$ as a result of its suburban location and higher biogenic emissions.

On mild ozone episode days (August 2-5, 1993; $T_{\max } 230^{\circ} \mathrm{C}$ ), both Rocky Point Park and Langley showed rather different isoprene profiles (Figure 4b). Isoprene concentrations at Langley on these days reached magnitudes of $0.8 \mathrm{ppbv}$ or more, while levels at Rocky Point Park peaked at $0.6 \mathrm{ppbv}$. The 3 episode days at Langley and Rocky Point Park showed increases in isoprene concentrations after dawn and elevated concentrations throughout the day. All three days exhibited small morning isoprene peaks, possibly as a result of anthropogenic morning rush-hour emissions. At Rocky Point Park, this peak occurred at 0600 hours (representing the average mixing ratio from 0600-0900 hours). At Langley, the morning peak occurred at $\mathbf{0 9 0 0}$ hours on both days. The later time of the morning peak at
Langley may reflect the amount of time required for the urban emissions of the Vancouver core to reach this suburban area.

It should be noted that the isoprene profiles observed on the 1993 episode days may not be typical of diumal profiles during major ozone events. The ozone episode of 1993 was mild, and $\mathrm{OH}$ concentrations were likely suppressed due to the high levels of $\mathrm{NO}_{\mathrm{x}}$.

4.2.2. Box model. To determine if the box model could account for typical isoprene concentrations and profiles observed in relatively simple systems, the model was run using data representative of a rural forest. For this simulation, a higher base emission rate was required. Lamb et al. [1985] estimated that the isoprene flux over a northeastern U.S. deciduous forest was $8000 \mu \mathrm{g} \mathrm{m}^{-2} \mathrm{~h}^{-1}$ at $30^{\circ} \mathrm{C}$. This value for $\mathrm{S}$ was entered into the model, along with the temperature profile at Rocky Point Park on August 5, $1993\left(\mathrm{~T}_{\max }=29^{\circ} \mathrm{C}\right)$ and a maximum mixing layer depth of $800 \mathrm{~m}$. Peak values of $\mathrm{OH}$ and $\mathrm{NO}_{3}$ were $1 \times 10^{6}$ radicals $\mathrm{cm}^{-3}$ and $10 \mathrm{ppt}$, respectively. The predicted profile is shown in Figure 5.

The model produces an isoprene profile similar to those measured over forests and published in the literature [e.g., Lamb et al., 1985; Fehsenfeld et al., 1992]. The predicted isoprene concentrations rise sharply after dawn, continue to rise throughout the day, and peak at a value greater than $10 \mathrm{ppbv}$ in the early evening. The peak in the early evening is the result of decreasing concentrations of $\mathrm{OH}$ radicals and the collapse of the mixing layer.

Figure $6 \mathrm{a}$ shows the predicted isoprene profiles on a representative nonepisode day at Rocky Point Park. For the nonepisode days, the box model successfully reproduced the relatively flat profile and low concentrations at both sites. In general, the predicted isoprene concentrations showed a very slight peak in the morning due to the combined effects of the shallow mixing layer and low concentrations of $\mathrm{OH}$ radicals, followed by a daytime minimum at noon that corresponded with the $\mathrm{OH}$ peak. Concentrations of isoprene rose slightly again in the late afternoon in response to decreasing $\mathrm{OH}$ concentrations and the collapse of the mixing layer. Rising levels of $\mathrm{NO}_{3}$ radicals were responsible for the decrease in isoprene after sunset.

Figure $6 \mathrm{~b}$ shows the predicted isoprene profile at Langley on the episode day August 2, 1993. As discussed previously, the measured isoprene profiles on these days were variable, and the box model was less successful at reproducing the observed patterns, although, in general, it made reasonable estimations of the magnitude of the isoprene mixing ratios. The most notable difference between days was the behavior of the isoprene profile in the late afternoon and evening. On August 2 (Langley), observed isoprene concentrations began to rise in the late afternoon and continued to rise throughout the evening. On August 4 (Langley), concentrations rose in the late afternoon, but fell sharply in the evening. Finally, on August 4 (Rocky Point Park), isoprene concentrations rose until midaftemoon and then decreased throughout the rest of the day and evening. The box model, on the other hand, predicted similar profiles on all 3 days, with predicted isoprene concentrations rising in the morning and continuing to increase throughout the day. The high predicted concentrations from noon to late in the afternoon were the result of active isoprene emissions increasing with temperature, combined with decreasing concentrations of $\mathrm{OH}$ radicals. Predicted levels of isoprene fell sharply in the evening in response to the modeled increasing concentrations of $\mathrm{NO}_{3}$.

There are two factors that may explain the observed afternoon and evening variations in isoprene profiles on episode days and why the model had difficulty reproducing these profiles. First, the time of the collapse of the boundary layer is important in determining whether isoprene concentrations show a substantial increase (other than the increase due to decreasing $\mathrm{OH}$ radical concentrations) late in the afternoon. If the boundary layer collapses before sunset while light levels are still sufficient for isoprene emission, ambient concentrations will increase as a result of the reduced dilution. The modeled profiles 


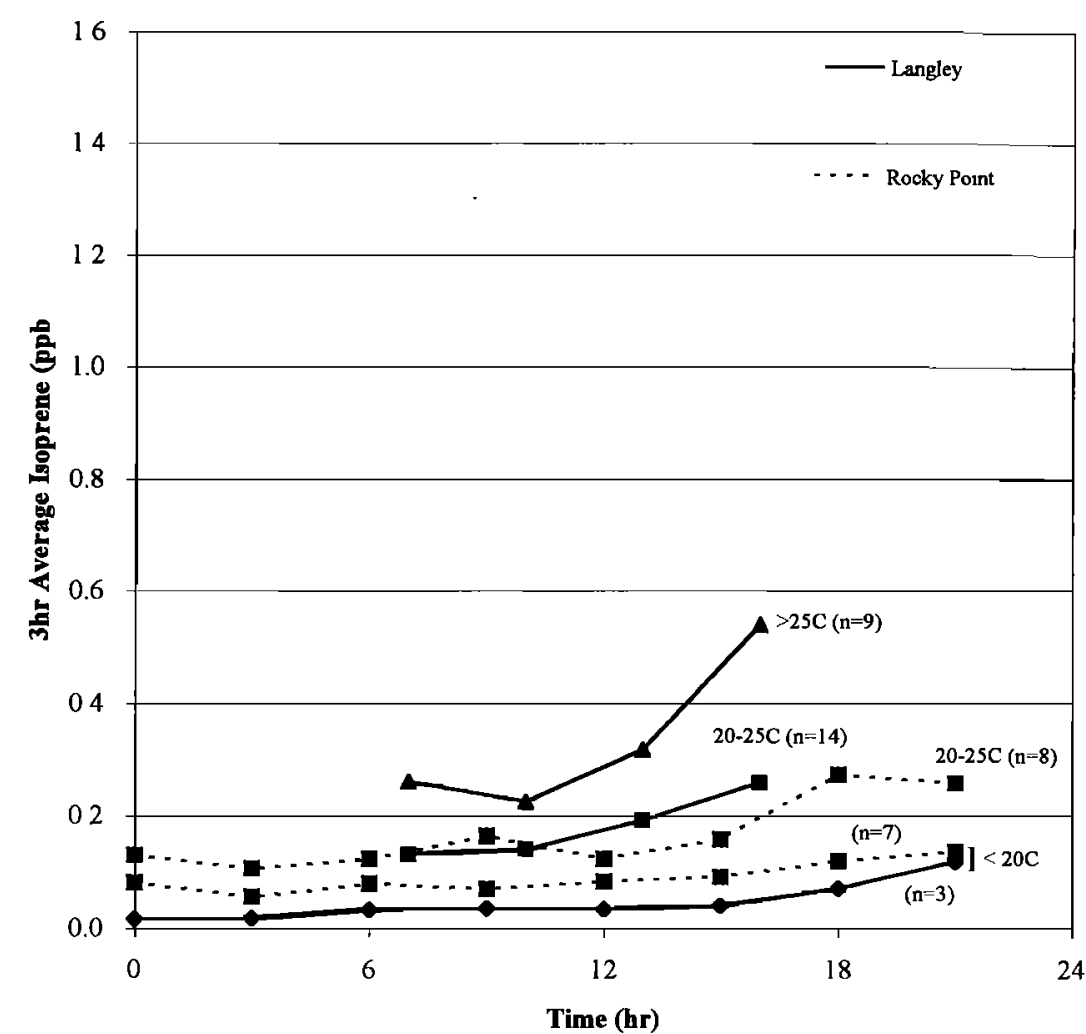

Figure 4a. Isoprene profiles on averaged non episode days.

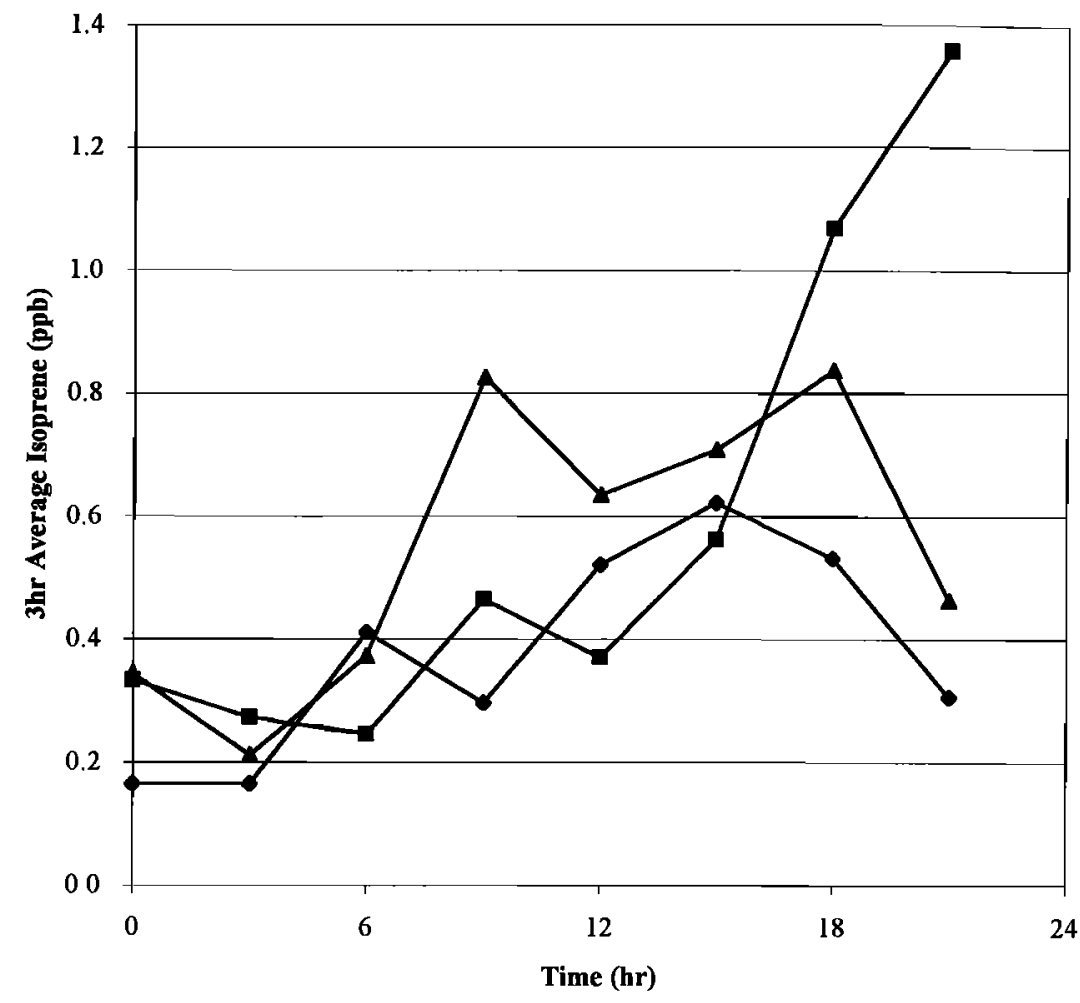

Langley, Aug $2 \rightarrow-$ Langley, Aug $4 \multimap-$ Rocky Point, Aug 5

Figure 4b. Isoprene profiles on episode days. 


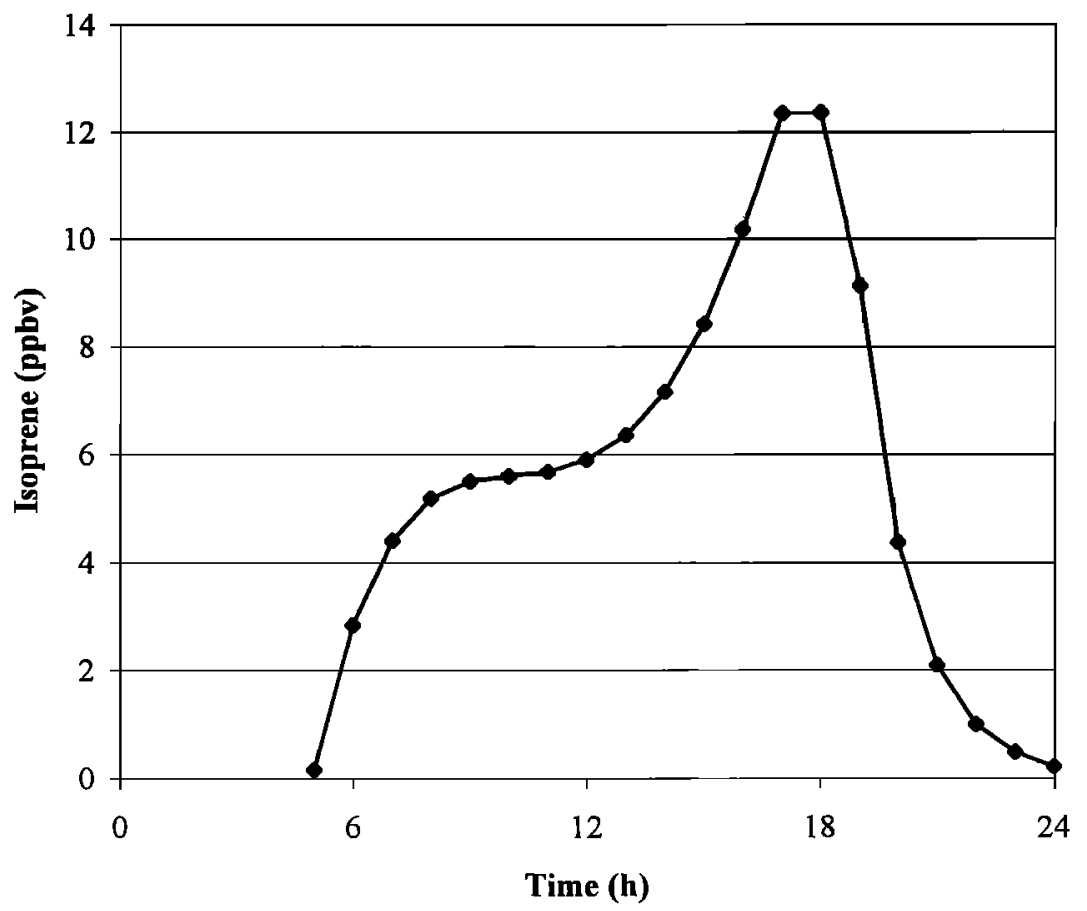

Figure 5. Predicted isoprene profile over a rural forest.

assumed that the boundary layer collapsed at the same time that the biogenic sources stopped emitting, thus negating this effect.

Second, the concentration and profile of nighttime $\mathrm{NO}_{3}$ concentrations is critical to explaining the behavior of isoprene after sunset. Measurements taken at experimental sites in West Germany showed that $\mathrm{NO}_{3}$ concentrations were very variable and that profiles changed substantially from night to night. $\mathrm{NO}_{3}$ concentrations at these sites ranged from not detectable to $280 \mathrm{ppt}$ [Platt et al., 1981]. No $\mathrm{NO}_{3}$ data from the Lower Fraser Valley were available for this analysis. $\mathrm{NO}_{3}$ profiles were assumed to rise quickly at sunset and to maintain a peak concentration of $10 \mathrm{ppt}$ for several hours. A slower increase in $\mathrm{NO}_{3}$ concentrations after sunset would result in higher evening isoprene concentrations.

\section{Conclusions}

The seasonal isoprene study described in this paper examined mean daily isoprene concentrations at several monitoring stations within the Lower Fraser Valley. As predicted by previous studies which found

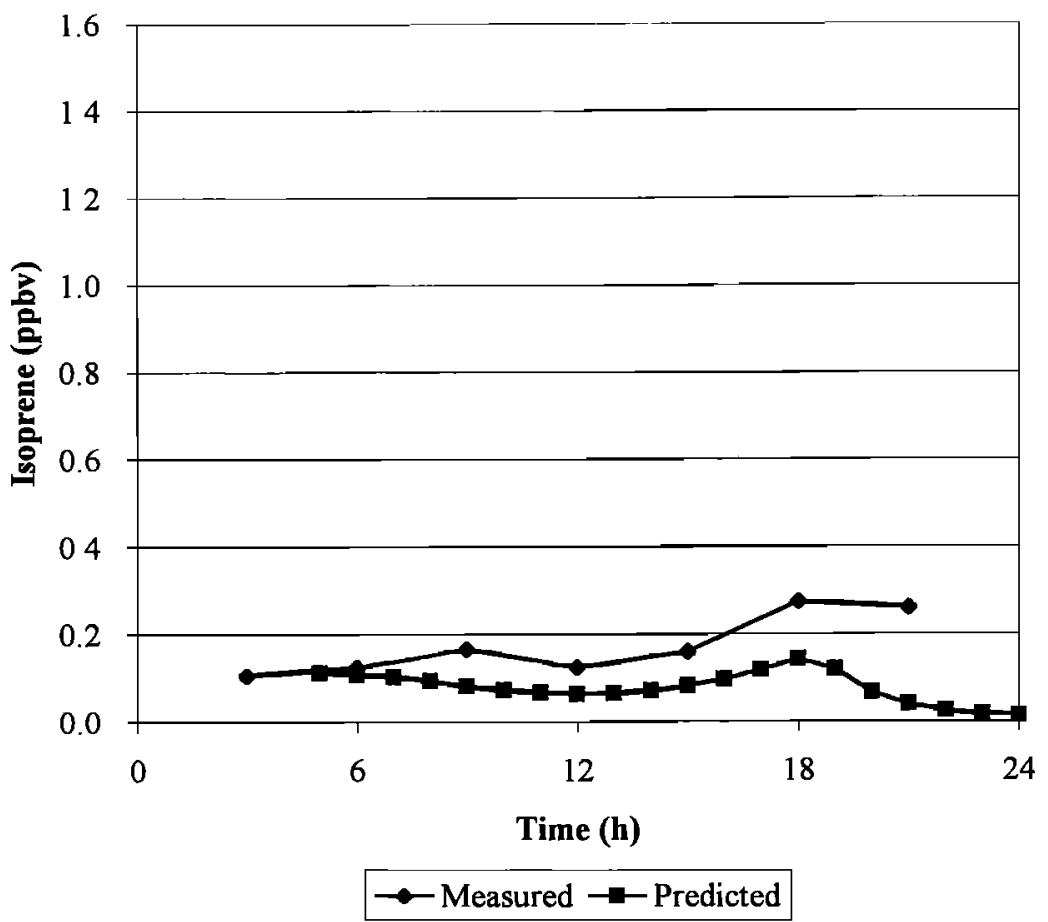

Figure 6a. Predicted and measured isoprene profile at Rocky Point Park; averaged days with $20^{\circ} \mathrm{C}<\mathrm{T}_{\max }<25^{\circ} \mathrm{C}$. 


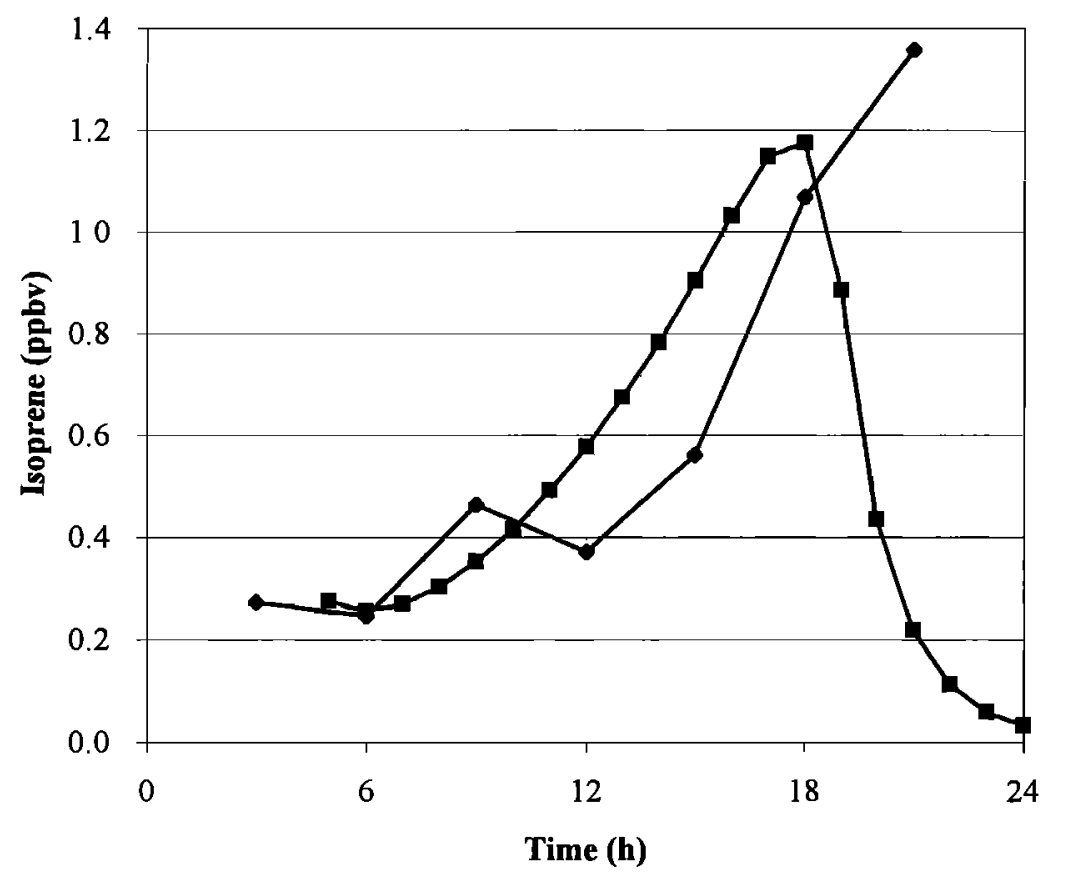

$\neg-$ Measured $\rightarrow$-Predicted

Figure 6b. Predicted and measured isoprene profile at Langley, August 2, 1993.

few species of isoprene-emitting vegetation in the region [Drewitt, 1996; Drewitt et al., 1997; Curren, 1998), daily mean isoprene mixing ratios at all of the urban and suburban sites examined were low throughout the year. Mean summer isoprene concentrations were approximately equal in magnitude to mean winter concentrations at urban sites and were slightly higher than mean winter concentrations at suburban sites. Although winter isoprene concentrations were enhanced by the shallow mizing layer of this season, the presence of isoprene in the atmosphere during the season when most plants are dormant indicates the existence of active local nonbiogenic sources of isoprene at the sites studied. Winter concentrations did not show any relationship with temperature, supporting the hypothesis of a nonbiogenic winter isoprene source. Detectable levels of isoprene were present at all sites on cool summer days when biogenic sources were relatively inactive, indicating a background anthropogenic level of isoprene during this season as well. Summer isoprene concentrations at temperatures greater than $15^{\circ} \mathrm{C}$ showed a clear relationship with temperature. These results suggest that winter isoprene mixing ratios are the result of anthropogenic emissions of isoprene, while summer concentrations are a mixture of both anthropogenic and biogenic isoprene.

The measured levels of isoprene showed strong positive correlations with cis-2-butene and trans-2-pentene, hydrocarbons normally associated with anthropogenic mobile sources, at all sites in both seasons. This is in contrast to the results reported for southern U.S. cities and indicates that a substantial portion of both the summertime and wintertime ambient isoprene load originates from anthropogenic mobile sources. Concentrations of isoprene on cool summer days (when biogenic sources are likely to be inactive) suggest that background anthropogenic isoprene may account for $25-78 \%$ of the total observed isoprene load at Rocky Point Park.

The diumal isoprene study examined the daily variation in isoprene concentrations in the Lower Fraser Valley and investigated the physical and chemical factors that defined the observed profiles through the use of a simple box model. On average, isoprene levels on nonepisode days at urban sites showed flat profiles and low concentrations of isoprene throughout the day. Higher isoprene levels were measured during the mild ozone episode days of 1993 and showed profiles that increased after sunrise and remained elevated throughout the day. There was some evidence of a moming isoprene peak due to rush hour related anthropogenic isoprene emissions on these days.

A simple box model was written to investigate the physical and chemical factors that determine the shape and the magnitude of isoprene profiles in the Lower Fraser Valley and to explain why the observed urban profiles were so much flatter in shape than those measured at rural sites over forests. The model included temperatureand light-dependent biogenic isoprene emissions, estimated anthropogenic isoprene emissions, a time-dependent mixing depth, daytime $\mathrm{OH}$ sinks, and nighttime $\mathrm{NO}_{3}$ sinks. The model successfully predicted both isoprene concentrations and profile shapes at urban sites on nonepisode days, and over forests, and was partially successful in estimating isoprene trends on chemically complex episode days.

The results of the model indicate that isoprene concentrations over deciduous forests are consistently high throughout the day as a result of the very high local areal emission rates that successfully compete with the effects of dilution due to a growing boundary layer and destruction by $\mathrm{OH}$ radicals. Isoprene emission rates at urban and suburban sites in the Lower Fraser Valley, on the other hand, are an order of magnitude lower than those at rural forest sites. At urban sites, daytime isoprene emissions fight a losing battle with the effects of a deepening mixing layer and destruction by $\mathrm{OH}$ radicals; low isoprene concentrations and flat diumal profiles are the result. The flat shape of the daytime isoprene profiles and low daytime concentrations lessen the potential impact of biogenic isoprene upon regional ozone production in the Lower Fraser Valley as the times of its highest concentrations (during the early evening) do not coincide with peak $\mathrm{NO}_{\mathrm{x}}$ concentrations nor with the times of optimal ozone-producing meteorological conditions.

The weight of evidence from this and previously published research suggests that biogenic isoprene is not a major contributor to the production of ozone in the Lower Fraser Valley. Few species of crops, 
natural vegetation, and trees in the region emit isoprene in appreciable amounts. As a result, ambient concentrations of total isoprene are correspondingly low throughout the day and in all seasons. Measurable concentrations of isoprene in winter and on cool summer days, as well as the positive correlation of isoprene with hydrocarbons known to be emitted from anthropogenic mobile sources, indicate that isoprene in the Lower Fraser Valley originates from both biogenic and anthropogenic sources; thus biogenic isoprene constitutes only a fraction of the small total isoprene load.

An analysis of isoprene's contribution to the total reactivity of nonmethane hydrocarbons in the Lower Fraser Valley showed that approximately $10 \%$ or less of the ozone produced at Langley results from reactions with isoprene [Bottenheim et al., 1997]. Isoprene's contribution to the formation of ozone was expected to be even less in more urban areas as a result of its lower abundance at those sites. This value is in good agreement with the analysis of Biesenthal et al. [1997], who used a separate and independent method to determine that approximately $13 \%$ of the ozone formed at another site in the Lower Fraser Valley was the product of reactions with isoprene. Together with the conclusions presented above, research suggests that biogenic isoprene may not be as important to the tropospheric ozone chemistry in the Lower Fraser Valley as it is in southern U.S. cities.

Acknowledgements. Funding for this research was provided by the Natural Sciences and Engineering Research Council and Environment Canada. Thanks to Weimin Jiang, National Research Council Canada, for providing temporal anthropogenic VOC profiles, and to Douw Steyn, University of British Columbia, and Nigel Bunce, University of Guelph, for advice and comments on this manuscript.

\section{References}

Biesenthal, T.A., Q. Wu, P.B. Shepson, H.A. Wiebe, K.G. Anlauf, and G.I. Mackay, A study of relationships between isoprene, its oxidation products and ozone in the Lower Fraser Valley, B.C., Atmos. Environ. 3/(14), 2049- 2058, 1997.

Bottenheim, J.W., P.C. Brickell, T.F. Dann, D.K. Wang, F. Hopper, A.J. Gallant, K.G. Anlauf, and H.A. Wiebe, Non-methane hydrocarbons and $\mathrm{CO}$ during Pacific '93, Atmos. Environ. 3l(14), 2079-2087, 1997.

Canadian Council of Ministers of the Environment (CCME), Canadian 1996 $\mathrm{No}_{2} / \mathrm{VOC}$ science assessment: Ground-level ozone and its precursors, report of the data anal. working group, Ottawa, Ont., Canada, 1997.

Cardelino, C.A, and W.L. Chameides, An observation-based model for analyzing ozone precursor relationships in the urban atmosphere, J. Air Waste Manage. Assoc. 45, 161-180, 1995.

Chameides, W.L. et al., Ozone precursor relationships in the ambient atmosphere, J. Geophys. Res., 97(DS)6037-6056, 1992.

Curren, K, Biogenic isoprene and the production of tropospheric ozone in the Lower Fraser Valley, British Columbia, Ph.D. thesis, Land Resour. Sci., Univ. of Guelph, Guelph, "Ontario, 1998.

Dann, T., D. Wang, A. Steenkamer, R. Halman, and M. Lister, Volatile organic compound measurements in the Greater Vancouver Regional District (GVRD), 1989-1992, Rep. PMD 94-1, Environ. Technol. Cent., Environ. Can., Ottawa, Ont., Jan. 1994.

Drewith, G., Measurement of biogenic hydrocarbon emissions from vegetation in the Lower Fraser Valley, British Columbia, M.Sc. thesis, 121 pp., Vancouver, B.C., Canada, Dep. of Geogr., Univ. of B.C., 1996.

Drewitt, G.B., K. Curren, D.G. Steyn, T.J. Gillespie, and H. Niki, Measurement of biogenic hydrocarbon emissions from vegetation in the Lower Fraser Valley, B.C., Atmos. Environ., in press, 1998.

Fetsenfeld, F., et al, Emissions of volatile organic compounds from vegetation and the implications for atmospheric chemistry, Global Biochem. Cycles, 6(4), 389-430, 1992.

Finlayson-Pitts, B.J., and J.N. Pitts, Atmospheric Chemistry: Fundamentals and Experimental Techniques, Wiley-Interscience New York, 1986.

Guenther, A.B., R.K. Monson, and R. Fall, Isoprene and monoterpene emission rate variability: Observations with eucalyptus and emission rate algorithm development, J. Geophys. Res., 96(D6), 10,799-10,808, 1991.

Hayden, K.L., K.G. Anlauf, R.M. Hoff, J.W. Strapp, J.W. Bottenheim, H.A Wiebe, F.A. Froude, and J.B Martin, The vertical chemical and metoorological structure of the boundary layer in the Lower Fraser Valley during Pacific '93, Atmos. Environ., 31(14), 2089-2105, 1997.

Hsu, S.A, A note on estimating the height of the convective internal boundary layer near shore, Boundary Layer Meteorol., 35, 311-316, 1986.

Jiang, W., D.L. Singleton, A Dorkalam, S. Bohme, and M. Hedley, Processing the Lower Fraser Valley Pacific 93 emission inventory for UAM-V applications: Area and mobile sources, Rep. PET1385-96S, Nat. Res. Counc.,Ottawa, Ont., Canada, Dec. 12, 1996.

Lamb, B., H. Westherg and G. Allwine, Biogenic hydrocarbon emissions from deciduous and coniferous trees in the United States,J. Geophys. Res., 90(D1), 2380-2390, 1985.

Levelton, B.H., Pacific 93 air emissions inventory draft report, B.H. Levelton \& Assoc. Ltd., Richmond, B. C., Canada, July 1996.

McLaren, R, D.L Singleton, J.Y.K. Lai, B. Khouw, E. Singer, Z. Wu, and H. Niki, Analysis of motor vehicle sources and their contribution to ambient hydrocarbon distributions at urban sites in Toronto during the southern Ontario oxidants study, Atmos. Environ., 30(12), 2219-2232, 1996.

National Research Council (NRC), Committee on Tropospheric Ozone Formation and Measurement, Rethinking the Ozone Problem in Urban and Regional Air Pollution, Nat, Acad, Press, Washington, D. C., 1991

Oke, T.R., Boundary Layer Climates, Methuen, New York, 1978.

Oliver, K.D., J.D. Pleil, and W.A. McClenny, Sample integrity of trace level volatile organic compounds in ambient air stored in summapolished canisters, Atmos. Environ., 20, 1403, 1986.

Parton, W.J., and J.A. Logan, A model for diumal variation in soil and air temperature, Agric. Meteorol., 23, 205-216, 1981.

Pierce, T.E., and P.S. Waldruff, PC-BEIS: A personal computer version of the Biogenic Emissions Inventory System,J. Air Waste Manage. Assoc., 41, 937-941, 1991.

Platt, U., D. Perner, J. Schröder, C. Kessler, and A. Toennissen, The diurnal variation of $\mathrm{NO}_{3}, J$. Geophys. Res., $86(\mathrm{Cl} 2), 11,965-11,970$, 1981.

Singleton, D., M. Hedley, W. Jiang, R. McLaren, T. Dann, and P.B. Shepson, Evaluation of isoprene emission and chemistry for photochemical and ozone modelling in the Lower Fraser Valley, British Columbias paper presented at the 89th Annual Meeting and Exhibition, Air and Waste Manage. Assoc., Nashville, Tenn., June 23-28, 1996.

Steyn, D.G., and T.R. Oke, The depth of the daytime mixed layer at two coastal sites: A model and its validation, Boundary Layer Meteorol., 24,161-180, 1982.

Steyn, D.G., J.W. Bottenheim, and R.B. Thomson, Overview of tropospheric ozone in the Lower Fraser Valley and the Pacific '93 study, Atmos. Environ., 31(14), 2025-2035, 1997.

Trainer, M., E.J. Williams, D.D. Parrish, M.P. Buhr, E.J. Allwine, H.H. Westberg, F.C. Fehsenfeld, and S.C Liu, Models and observations of the impact of natural hydrocarbons on rural ozone, Nature, 329, 705-707, 1987.

Venkatram, A, A model for internal boundary layer development, Boundary Layer Meteorol., 11., 419-437, 1977.

Winberry, W.A., Jr., N.T. Murphy, and R.M. Piggan, Method TO-14 and Method TO-13, in Compendium of Methods for the Determination of Toxic Organic Compounds in Ambient Air, Rep. EPA-600/4-89-017, U.S. Environ. Prot. Agency, Research Triangle Park, N. C., June 1988.

K. Curren and T. Gillespie, Land Resource Science, University of Guelph, Guelph, Ontario, Canada N1G 2W1. (e-mail: tgillesp@lrs.uoguelph.ca).

T. Dann and D. Wang ETC, Environment Canada, River Road, Ottawa, Ontario, Canada K1A OH3.

(Received November 25, 1997; revised March 31, 1998 ; accepted April 7, 1998.) 